\title{
Woodland Period Archaeology as seen from the Attoyac Bayou Basin in East Texas
}

Timothy K. Perttula

Heritage Research Center, Stephen F. Austin State University

Follow this and additional works at: https://scholarworks.sfasu.edu/ita

Part of the American Material Culture Commons, Archaeological Anthropology Commons, Environmental Studies Commons, Other American Studies Commons, Other Arts and Humanities Commons, Other History of Art, Architecture, and Archaeology Commons, and the United States History Commons

Tell us how this article helped you.

This Article is brought to you for free and open access by the Center for Regional Heritage Research at SFA ScholarWorks. It has been accepted for inclusion in Index of Texas Archaeology: Open Access Gray Literature from the Lone Star State by an authorized editor of SFA ScholarWorks. For more information, please contact cdsscholarworks@sfasu.edu. 


\section{Woodland Period Archaeology as seen from the Attoyac Bayou Basin in East}

Texas

\section{Creative Commons License}

(c) (1) (8)

This work is licensed under a Creative Commons Attribution-NonCommercial 4.0 International License 


\title{
Woodland Period Archaeology \\ AS SEEN FROM THE \\ AtToyac Bayou Basin in East TeXas
}

\author{
Timothy K. Perttula
}

\begin{abstract}
The character of the archaeological record of the Woodland period (ca. 550 B.C.-A.D. 800) in East Texas is discussed in the context of the findings from excavations at four Mossy Grove Culture Woodland period sites at Lake Naconiche in the Attoyac Bayou basin. Of particular concern is information obtained from these sites on local Woodland period settlement patterns and features, and hints of a developing sedentism in the latter part of the period (after ca. A.D. 500/600), subsistence strategies and the use of cultivated plants, their material culture (chipped and ground stone tools and the manufacture and use of ceramic vessels), and evidence in the archaeological record for exchange and interaction between neighboring Woodland groups. The Mossy Grove Culture Woodland period groups that lived at the Lake Naconiche sites were relatively parochial huntinggathering foragers with a mobile settlement system characterized by intermittently occupied camps, and a material culture dominated by plain sandy paste pottery, dart points and bifaces, and expedient tools.
\end{abstract}

\section{Introduction}

The indigenous Woodland (ca. 2500-1150 years B.P.) period cultures in East Texas and other parts of the Caddo archaeological area are considered to represent the direct ancestors of the Caddo Indian peoples (see Early 2004; Schambach 2001, 2002; Story 1990; Wyckoff 1980). The roots of the Caddo peoples can be traced to several ancestral Woodland period culture groups of varying socio-political complexities, including the Fourche Maline (Schambach 2002), Mill Creek (Perttula and Nelson 2004), and Mossy Grove (Story 1990) cultures (Figure 1). Although the processes involved in the development of the Caddo archaeological tradition are still rather murky (see Girard 2009a, 2009b), it appears to be the case that after ca. A.D. 800, what had been Woodland period communities began to settle down in dispersed communities throughout the region, to manufacture distinctive utility ware, fine ware, and plain ware ceramics for cooking and storage of foodstuffs, and to develop a horticultural way of life based on the raising of tropical cultigens (corn, squash, and later beans) and certain native plants (Early 2004:560-566).

Recent excavations at a series of sites with Mossy Grove Woodland period components at Lake Naconiche in the Attoyac Bayou basin (Perttula 2008, editor) obtained substantial archaeological data on the character of Woodland sites in one part of East Texas (Figure 2). These sites are Tallow Grove (41NA231), Naconiche Creek (41NA236), Beech Ridge (41NA242), and Boyette (41NA285). Excavations were also completed at the Foggy Fork site (41NA235), but only a minimal Woodland period component was identified there. In particular, information is available on their settlement character and whether they had developed a sedentary lifeway, subsistence strategies, the nature of their material culture assemblages, especially the development, adoption, and use of ceramic vessels, and evidence from ceramic and lithic artifacts of interaction with other Woodland period groups. 


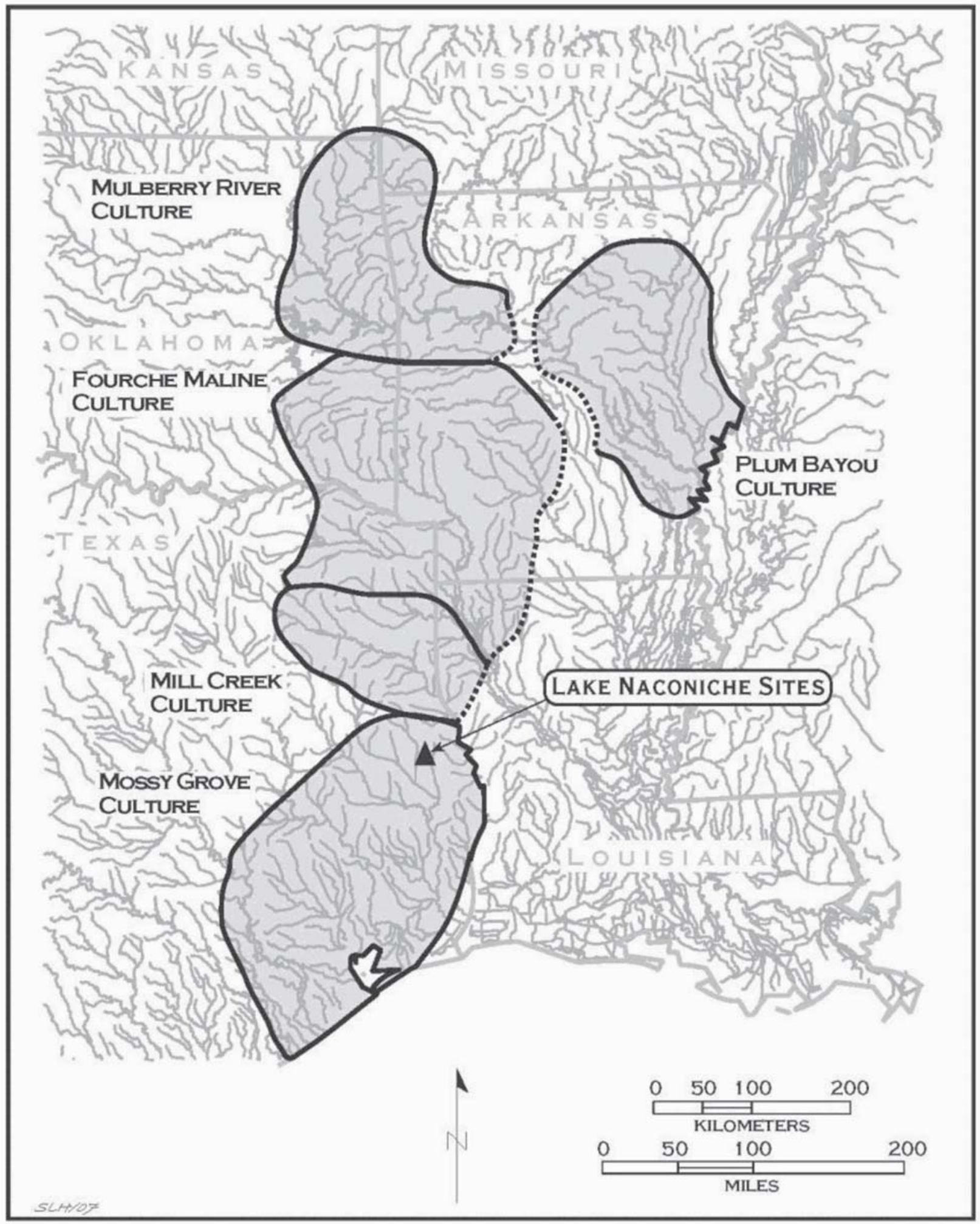

Figure 1. Map of Woodland cultures in the Caddo archaeological area, including the Mossy Grove and Mill Creek Cultures, and the Plum Bayou culture of the Lower Mississippi River basin. 


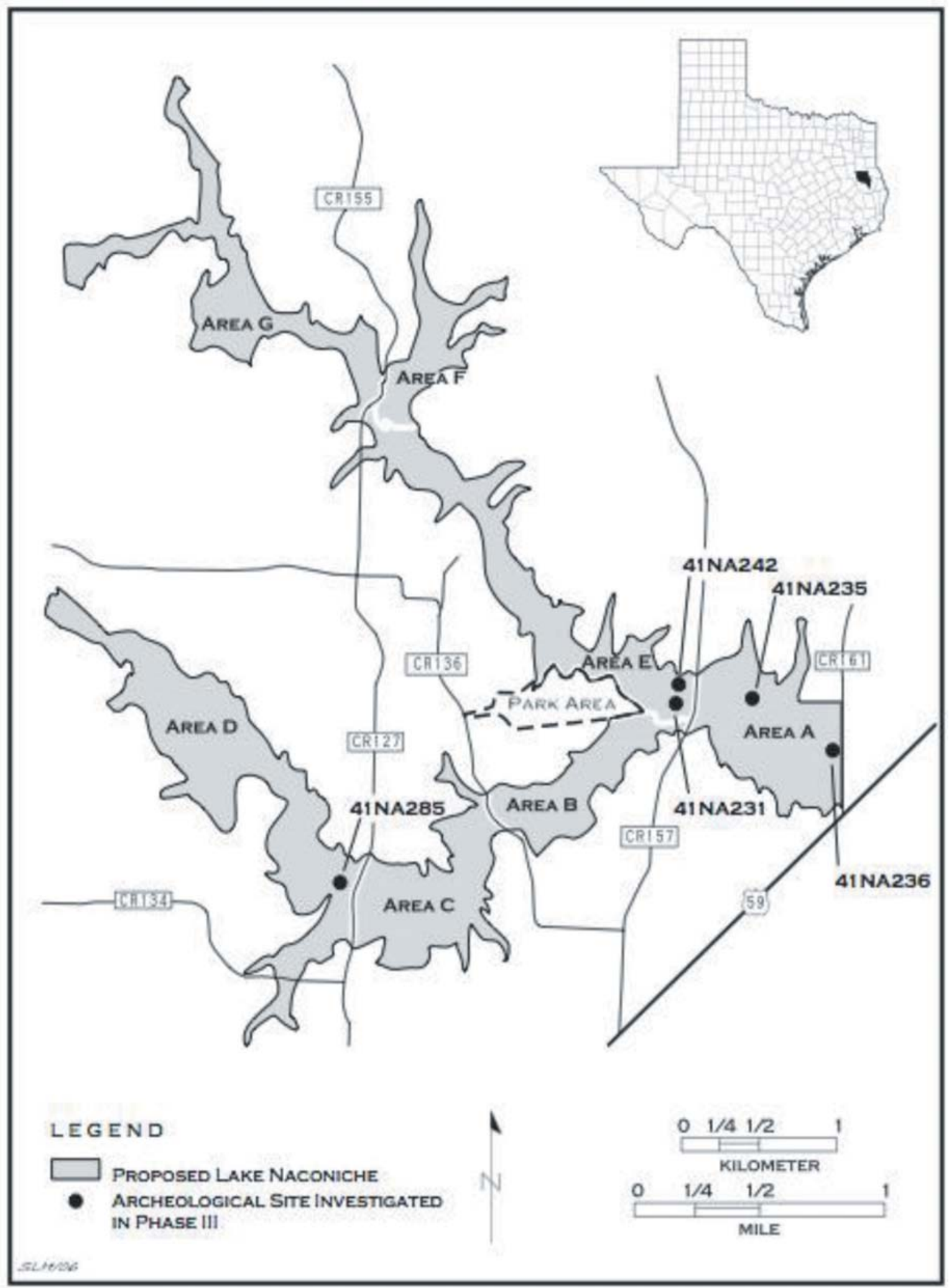

Figure 2. The Lake Naconiche project area on Naconiche Creek, and locations of sites that received data recovery investigations. 


\section{East Texas Woodland Period Archaeology}

The Mossy Grove Culture encompasses Woodland period archaeological sites from the upper Texas Coast well into East Texas, as far north and east as the Sabine River basin, including the upper part of the Attoyac Bayou basin where the Lake Naconiche sites lie (see Figure 1). At least in some cases, the prehistoric peoples that we refer to conveniently as the inland groups of the Mossy Grove culture are considered likely to be ancestral to the prehistoric Caddo groups living in this part of East Texas after ca. A.D. 800, and as such are also ancestral to their descendants, the modern Caddo Nation of Oklahoma. Certainly not all Mossy Grove culture groups living in southeastern and eastern Texas are ancestral to the Caddo, and Corbin (1989) has suggested-and Story 2000:12,25) also alludes to the possible contemporaneity of the Caddo and Mossy Grove groups, rather than an ancestral-descendant connection-that Mossy Grove groups were contemporaries of the earliest Caddo to live in East Texas, and that gradually over time these Woodland groups adopted Caddo lifeways.

Extensive excavations have been limited at inland Mossy Grove sites in East Texas, or at least excavations on those sites that have been published (i.e., Corbin 1989, 1998). The Deshazo site (41NA27) on Bayou Loco is probably the most thoroughly excavated and studied Mossy Grove site in East Texas (Story 1982, 1995). There, a large assemblage of stone tools and sandy paste pottery sherds (5\% of which were decorated) were found on an alluvial fan above Bayou Loco, a tributary to the Angelina River (Girard 1995; Fields 1995:177-180 and Figure 58c-h). No features or midden deposits were identified in this component, nor were any plant or animal remains recovered that would have been informative about the subsistence pursuits of the Mossy Grove peoples that used the site intermittently more a considerable period of time (Story 1995:237).

Tunnell (1961) encountered similar sorts of Mossy Grove occupations at the Runnells \#1 (41SA87), Runnells \#2 (41SA86), and Sawmill (41SA89) sites at Lake Sam Rayburn on the Angelina River downstream from the Deshazo site. There were no midden deposits or intact cultural features, and the Woodland period components contained Gary and Kent dart points, plain sandy paste pottery sherds, pitted stones, and a heavy use of local petrified wood and chert stream pebbles.

A contemporary Woodland culture is the Mill Creek Culture (see Perttula and Nelson 2004). The boundaries of the Mill Creek Culture (see Figure 1) suggest that sites belonging to the culture are found in the middle Sabine and Big Cypress stream basins. There have not been many investigated and well-dated Woodland period sites in this part of East Texas (see Story 1990; Rogers et al. 2001; Perttula and Nelson 2004). The Mill Creek Culture is contemporaneous with the Fourche Maline (see Schambach 1982, 1998, 2002) and Mossy Grove cultures to the north and south (see Figure 1). Mossy Grove and Mill Creek Culture sites appear to date between ca. 2400-1150 years ago. Probably the best known Mill Creek Culture site is the Herman Ballew site (41RK222) on Mill Creek (Rogers et al. 2001), a tributary to the Sabine River in the central part of Rusk County, Texas. Although no structures were identified at Herman Ballew, there were numerous features in the Woodland period component, including three fire-cracked rock scatters, seven rock-lined hearths or earth ovens, and seven pits; several of the pits had a charcoal-rich fill, probably from use as cooking pits, while one large pit (2.5 $\mathrm{m}^{3}$ of fill) may have been originally intended for use as a storage pit (Rogers et al. 2001). Such storage pits hint at the possibility of extended stays by certain Woodland groups that occupied the site; there were no midden deposits here, however. At the Resch site (41HS16), another Mill Creek culture site on a tributary to the Sabine River, apparently occupied between about 400 B.C. and A.D. 300 (see Perttula 1998:330), midden deposits about 1 acre in size were present, as well as four possible post holes, five fire-cracked rock clusters, and eight ash/ charcoal stains (Webb et al. 1969). Webb et al. (1969:97) note, however, "an absence of permanent habitations" at Resch, with "brief occupations by small groups, probably no more than family or extended family size, but returning time after time."

\section{8 - Volume 23, 2013}




\section{Lake Naconiche Woodland Period Archaeological Record}

The Woodland period occupations at the Lake Naconiche sites are components of the Mossy Grove Culture (see Figure 1) defined by Story (1990). These represent occupations specifically of inland groups of that culture that lived in the Neches River, Angelina River, and Attoyac Bayou stream basins in the Pineywoods of East Texas. The sites were occupied during periods of generally cooler climate with periods of widespread vegetation change, with very dry and cool episodes at ca. 2300 and 2000 years ago (Perttula and Nelson 2004:Figure 4). The period between ca. 1800-1000 years was one of rapidly and widely fluctuating climates, with colder and drier periods at ca. 1700 B.P., ca. 1500 B.P., and ca. 1200-1150 B.P. (see Bradley et al. 2003:Figure 6.13), interspersed with warmer and wetter conditions. Warm periods culminated around 1000 years ago, during the early part of the prehistoric Caddo tradition in the region.

The Woodland period occupations at the Lake Naconiche sites date from as early as 520 B.C. at the Naconiche Creek site and as late as the $9^{\text {th }}$ century A.D. at the Boyette site, based on 16 calibrated radiocarbon dates (Table 1). Half of the calibrated age ranges of the dates occur in the period after A.D. 400, which temporally correlates with a substantial increase in radiocarbon-dated Woodland period sites across East Texas (Selden 2012).

The archaeological deposits at these Woodland sites are marked by a scattering of lithic tools and debris, some sandy paste ceramic sherds, fire-cracked rocks, and ground stone tools. Features are rare, and midden deposits are absent at this time on even the more intensively occupied Woodland period components. The general dearth of features, no midden deposits, as well as the low density of recovered materials, are indicative of periodic use of the Lake Naconiche sites over the span of more than 10 centuries, certainly by mobile hunting-gathering foraging groups. The presence of ceramics hints at the beginnings of a more settled way of life, as the manufacture and use of ceramic vessels for cooking, storage, and food-serving implies that more extended stays may have occasionally taken place at the sites, perhaps during the latter part (after ca. A.D. $500 / 600$ ) of the Woodland period.

\section{Settlement Patterns and Sedentism}

Did an increasing sedentism affect the character of material culture remains at the Lake Naconiche sites, the types of features and facilities in Woodland period components, as well as the underlying nature of these settlements? As best as can be discerned in the archaeological records of the Woodland occupations at the Naconiche Creek and Boyette sites, if there is any evidence of increasing sedentism, it is only apparent after ca. A.D. 400 or perhaps even as late as ca. A.D. 650, during the latter part of the period. Even so, these occupations were not sedentary in the sense of them being year-round occupations or even multi-seasonal occupations. The sites do not have accumulations of midden deposits, there is no evidence for the construction of sturdy wood structures, and there are only a very modest assortment of burned rock, pit, or post hole features at the Woodland period sites. It is hard to disagree with Story's (1995:237) characterization of Woodland period settlements in the general area that they reflect "intermittent encampments by a relatively small group or groups over a considerable period of time."

Woodland period sites are widely distributed on many different kinds of landforms, implying the generalized use of a wide variety of habitats for settlements as well as foraging pursuits. Woodland period sites at Lake Naconiche are found in both alluvial ad upland settings, and are widely distributed across the Naconiche Creek basin. Without a more fine-grained Woodland period chronology for Mossy Grove culture 
sites in East Texas, which we are a long way from achieving, it is not possible to evaluate suggestions by Corbin (1998) that there were subtle shifts on the landscape of Woodland peoples that may have been a response to changes in subsistence (i.e., the possible growing of cultivated plants). The absence of cultigens other than squash from Woodland contexts in the Lake Naconiche paleobotanical record casts some doubt on the assertion that horticultural economies were developed during this time locally, although the number of flotation and finescreen samples from pre-A.D. 800 contexts is still miniscule (Perttula 2008:Table 2). Thus, the virtual absence of cultigens from Woodland times does not yet constitute a robust evaluation of Corbin's suggestion.

Table 1. Woodland Period Radiocarbon Dates from the Lake Naconiche Sites.

\begin{tabular}{lllll}
\hline Beta No. & Provenience & $\begin{array}{l}\text { Conventional } \\
\text { Age (B.P.) }\end{array}$ & $\begin{array}{l}\text { 1 Sigma, cal } \\
\text { (A.D./B.C.)* }\end{array}$ & $\begin{array}{l}\text { 2 Sigma, cal } \\
\text { (A.D./B.C.)* }\end{array}$ \\
\hline 41NA231 (Tallow Grove site) & & & \\
& & & \\
B-136806 & ST 405, $40-80 \mathrm{~cm}$ & $1680+40$ & A.D. 333-415 (0.62) & A.D. 245-434 (0.95) \\
B-204778 & Unit 90, $40-60 \mathrm{~cm}$ & $1960+70$ & 42 B.C.- A.D. $90(0.60)$ & 116 B.C.-A.D. 221 (0.93)
\end{tabular}

41 NA236 (Naconiche Creek Site)

\begin{tabular}{|c|c|c|c|c|}
\hline B-183857 & Feature $18,50-65 \mathrm{~cm}$ & $1380+60$ & A.D. $598-688$ (0.68) & A.D. 558-773 (0.95) \\
\hline B-203667 & Feature $5,50-60 \mathrm{~cm}$ & $1420+90$ & A.D. 537-689 (0.67) & A.D. $420-778(0.95)$ \\
\hline B-204783 & Unit 72/81, 90-100 cm & $1470+40$ & A.D. $565-635$ (0.68) & A.D. 534-655 (0.94) \\
\hline \multirow[t]{2}{*}{ B-203666 } & Feature $4,44-70 \mathrm{~cm}$ & $1560+40$ & A.D. $434-495$ (0.42) & A.D. $415-585$ (0.95) \\
\hline & & & A.D. 504-543 (0.26) & \\
\hline B-204782 & Feature $17,20-40 \mathrm{~cm}$ & $1830+40$ & A.D. $134-240(0.68)$ & A.D. $80-258(0.93)$ \\
\hline B-203669 & Unit $57-59,70-80 \mathrm{~cm}$ & $1850+90$ & A.D. $61-256(0.66)$ & 39 B.C.-A.D. 385 (0.95) \\
\hline B-151097 & Unit $3 / 5,50-70 \mathrm{~cm}$ & $1910+40$ & A.D. $52-132(0.66)$ & A.D. 5-216 (0.95) \\
\hline B-203668 & $\begin{array}{l}\text { Unit } 23-24,31-32 \text {, } \\
60-70 \mathrm{~cm}\end{array}$ & $2010+60$ & 60 B.C.-A.D. 65 (0.61) & 174 B.C.-A.D. 90 (0.93) \\
\hline \multirow[t]{2}{*}{ B-151098 } & Unit 3/5, 70-90 cm & $2370+40$ & 510-436 B.C. (0.43) & 546-382 B.C. $(0.87)$ \\
\hline & & & 426-393 B.C. $(0.26)$ & \\
\hline
\end{tabular}

41 A285 (Boyette Site)

\begin{tabular}{|c|c|c|c|c|}
\hline B-221421 & Feature $1 / 9,60-87 \mathrm{~cm}$ & $1240+40$ & $\begin{array}{l}\text { A.D. } 690-752(0.36) \\
\text { A.D. } 788-815(0.13) \\
\text { A.D. } 761-783(0.12)\end{array}$ & A.D. $680-882$ (0.95) \\
\hline B-201990 & Feature $1 / 14,60-80 \mathrm{~cm}$ & $1260+40$ & A.D. $680-779$ (0.68) & A.D. $668-870(0.95)$ \\
\hline B-204786 & Feature $1 / 10,74-90 \mathrm{~cm}$ & $1330+40$ & A.D. $652-695$ (0.50) & A.D. $643-774$ (0.95) \\
\hline B-151112 & Unit $7 / 12,40-60 \mathrm{~cm}$, & $2090+40$ & 166-54 B.C. (0.68) & 204 B.C.-A.D. 2 (0.95) \\
\hline \multirow[t]{3}{*}{ B-201989 } & Feature $35,100-108 \mathrm{~cm}$ & $2150+40$ & 210-151 B.C. $(0.32)$ & 260-87 B.C. $(0.62)$ \\
\hline & & & 351-299 B.C. (0.24) & 359-277 B.C. (0.30) \\
\hline & & & 140-112 В.С. $(0.11)$ & \\
\hline
\end{tabular}

*Calibrations and probabilities follow Selden (2012:Table 2) 
The development of sedentary life along Naconiche Creek appears to have taken place after ca. A.D. 800 by certain successful hunter-gatherer foragers and pottery makers, specifically amongst the earliest Caddo residents of the valley. Neither the adoption of pottery or the adoption of horticultural subsistence strategies (i.e., the cultivation of maize) appear to have been triggering events that led to the ability of these people to maintain multi-seasonal residences in the same places.

Another research concern is the lack of a suitable understanding with regard to the nature of individual dwellings, features, and storage facilities that may be present in excavations in Woodland period components for this part of East Texas. If such features are present, how are they arranged spatially and functionally? These types of data sets may directly address the stability or permanence of the Woodland period occupation(s) over a several hundred year period at these locales.

Only a few cultural features were identified in archaeological deposits that date to Woodland period times at the Tallow Grove, Naconiche Creek, and Boyette sites. These features include fire-cracked rock concentrations, ground stone tool caches, one large pit, small pits, and a few post holes. Those features that have been radiocarbon dated fall primarily in the temporal interval from cal A.D. 430 to A.D. 780 ( $n=6)$, with two others from the Naconiche Creek and Boyette sites dating from cal 360 B.C. to A.D. 260 (see Table 1). Although the small number of features-dated or otherwise-is not much evidence to base speculations on settlement permanence or stability by Woodland period groups, the increasing number of post-A.D. 430 dated features at the Lake Naconiche sites suggests that a repeated and somewhat more intensive Woodland period use of the Naconiche Creek valley dates after that time.

The kinds of features identified at the Lake Naconiche sites suggest their use for cooking with hot rocks and plant and animal processing activities, and these appear to have been the principal focus of Woodland occupations. A large $7^{\text {th }}$ and $8^{\text {th }}$ century pit feature at the Boyette site may have been an earth oven or some sort of outdoor cooking feature; its large size suggests the mass processing of wild plant foods there, or perhaps it was used as a storage feature for bulk foods such as nut meats and oils.

The few possible early post holes uncovered at the Tallow Grove, Naconiche Creek, and Boyette sites leaves open the possibility that structures may have been erected at the time of the Woodland period occupations. It is probably more likely that the post holes represent evidence for stands or racks used to dry meats or hides since there are so few of them, and that the structures that were in use were so temporary as to elude archaeological detection. These hypothetical structures were likely brush and hide-covered affairs that did not require well-set posts to hold them up, and were likely composed of structural or support posts or saplings that probably sat atop the ground surface.

At the Naconiche Creek site, the Woodland period features were identified stratigraphically below the Caddo midden deposits. They were distributed across the block excavations, but formed no recurrent or coherent spatial arrangement. The features in Woodland contexts at the Boyette site are concentrated in the northern part of Block I, where there are relatively deep archaeological deposits in alluvial deposits underlying the Caddo occupation. The three features discovered there have calibrated radiocarbon ages that range (at 2 sigma) from A.D. 650-890, at the very end of the Woodland period. 


\section{Subsistence}

What strategies of subsistence resource utilization are represented in the Woodland period archaeological record at the Lake Naconiche sites? It would be important to demonstrate that domesticated plants were being grown and eaten, as Schambach (2001) suggests is the case for Woodland period groups, at least in terms of the cultivation of oily and starchy seeds and squash, if not the cultivation and use of maize. Nuts, seeds, tubers, and roots were likely important to the Woodland period occupants at the Naconiche Creek and Boyette sites. It has been suggested that changes in the density and placement of Woodland period sites across the East Texas landscape may be congruent with evidence that horticultural practices may have been introduced during Woodland period times, or that there were population shifts "tied to ... moving closer to a significant plant food source (i.e., plants that were restricted to valley margins and/or the floodplain) whose use was facilitated by processing via cooking in ceramic vessels" (Corbin 1998:114-115).

No domesticated plants were recovered in Woodland period contexts at Lake Naconiche, except for a fragment of squash rind at the J. Simms site (41NA290) (Perttula 2002), upstream on Telesco Creek from the Boyette site (see Figure 2). This particular cultigen was recovered in archaeological deposits that postdate ca. A.D. 400. Plant foods found in Woodland period sites are dominated by hickory nuts, indicative of the importance of hardwood nut foraging and processing of hickory nuts for oils and nut meats.

The limited regional scope of the Lake Naconiche archaeological investigations is not sufficient to adequately address the question of whether there were spatial shifts across the landscape in the density and placement of Woodland period sites. Another difficulty that would need to be addressed that is currently hindering Woodland period archaeological studies in East Texas is the very poor understanding of the specific ages of components and how long such components were occupied (or re-occupied). Without better temporal control-comparable to what has been achieved in Caddo archaeological studies in East Texas-it would be futile to attempt to identify subtle spatial and settlement shifts across the landscape during the 1300 year Woodland period.

The fact that more than $94 \%$ of the archaeological sites at Lake Naconiche with identifiable archaeological components (see Perttula 2002:Table 11.1) have Woodland period occupations-although none are particularly substantial-indicates that Woodland groups lived broadly but lightly across this part of the East Texas landscape. Woodland sites occur on a variety of landforms, with no hint that particular places or environmental habitats were preferred for settlement and use over another.

What were the most important game animals being exploited by Woodland period populations? A variety of woodland and aquatic animal resources were probably exploited during the early occupations at the Naconiche Creek and Boyette sites. The different kinds of wood represented in the charcoal provide information on the character of the overstory vegetation in the immediate vicinity of the sites.

White-tailed deer was the most important game animal procured by the Woodland period occupants at the Naconiche Creek and Boyette sites, with some meat and/or pelts contributed by medium-sized mammals and turtles; although preservation conditions may be a factor, fish and birds were only rarely taken. It seems that wooded edge habitats-perhaps kept brushy by periodic firings, as was the case among the Caddo living later in the Pineywoods-were a preferred habitat to seek out game, based on the predominance of white-tailed deer in Woodland faunal assemblages at Lake Naconiche (Perttula 2008, editor), as were forested bottomlands. 
The wood charcoal found in Woodland period contexts are indicative of a Pineywoods environmental setting, with oak and pine the principal trees in the overstory. This vegetational association is characteristic of the modern overstory along Naconiche and Telesco creeks, and thus the recovered wood charcoal provides only an indication that the most abundant wood sources were exploited for use in fires at that time, and no evidence relevant to ascertaining paleoenvironmental changes, periodic droughts, or fire episodes.

The introduction of the bow and arrow hunting technology after ca. A.D. 700 (Shafer and Walters 2010), and changes in cooking technology with the early use of ceramics, may have affected Woodland period subsistence strategies. It is suspected that both technologies played important roles in structuring and affecting the character of subsistence strategies near the end of the Woodland period in particular. Certainly large game animals were successfully procured by Woodland period hunters, as attested to by recovered faunal remains at the Naconiche Creek and Boyette sites, but we were not able to isolate discrete Woodland period archaeological deposits that contained only Gary and Kent dart points or deposits that contained only early forms of arrow points (i.e., dating after ca. A.D. 700) to compare the range of species procured at these different times, or their relative proportions.

Cooking in ceramic pots versus employing direct heating in open fires or indirect heating using hot rocks or boiling stones may have broadened the range of foods (including both plant foods and game animals) that could be readily or more efficiently cooked by Woodland period groups at Lake Naconiche. That being said, while such a technology could have permitted use of a broader range of foodstuffs, there is no archaeological evidence from Woodland period contexts that a broader range of foods were being procured or processed at that time. However, the familiarity of these peoples with a ceramic cooking technology-even in its infancy in the first millennium A.D.-would have created conditions where such foods could be more efficiently cooked if and when such foods (i.e., cultigens) became known to them or their Caddo descendants. Perhaps even more important for elaborations in cooking technologies than the adoption of a bow and arrow technology in this respect was the maintenance of a diverse ground stone tool kit that was able to successfully finely grind different plant foods that could be cooked in ceramic pots.

These Woodland cultures in the Sabine, Big Cypress, Angelina, and Attoyac stream basins were hunter-gatherers that relied upon the natural abundance of the northeastern Texas woodlands for subsistence, although it is possible that these cultures did grow some cultigens; squash has been recovered in Woodland period contexts among groups living in the upper Sulphur River basin, for example (see Story 1990) and at one site at Lake Naconiche that has a post-A.D. 400 occupation. Seed crops were probably not widely used as stored foods for winter use, as the "relatively mild temperatures [of this part of northeastern Texas] limit the length and severity of the winter season and therefore the degree of reliance on stored foods" (Gremillion 2002:498) in pre-maize Woodland period times.

At the Herman Ballew site, few charred plant remains were recovered in the Woodland period archaeological deposits (see Rogers et al. 2001:94), even though a number of pit features were excavated and their deposits subjected to flotation. These remains included 220+ seeds of bedstraw (Galium sp.), goosefoot/ pigweed (Chenopodium sp.), and grass (Poaceae sp.), hickory nutshells (14.5 g), walnut nutshells ( $0.8 \mathrm{~g}$ ), and a small amount of wood charcoal (0.9 grams), including oak wood (Dering 2001). The nut: wood ratio is a very high (17.0:1) in the Herman Ballew component, suggesting a considerable dependence on nut plant foods (e.g., Dering 2002:318). 
Farther afield, plant food remains have also been recovered at the Tick (41DT6) and Spike (41DT16) sites in Woodland period components that date from ca. A.D. 50-700 and A.D. 0-800, respectively, in the upper Sulphur River basin in East Texas (Fields et al. 1997). Those deposits were dominated by nutshells-including hickory, acorn, and pecan-along with a few seeds of vetch/peavine and wild plum, and some Pediomelum rhizome fragments from roots. Cultivated squash was recovered at another Woodland period site (41HP137) in the same part of the South Sulphur River basin (Fields et al. 1997:Table 11).

\section{Material Culture}

\section{Lithic Assemblages}

What is the character of a Woodland period lithic tool assemblage, and how does its composition and character relate to the emergence of sedentism by Woodland period peoples? The lithic tools and debris from tool manufacture that are found in a contextually discrete Woodland period component are informative about tool use, discard, curation, and raw material procurement, and may be informative in turn about changes in mobility and resource utilization in the latter part of this period.

The Woodland period lithic tool assemblages from the Lake Naconiche sites are dominated by hafted dart points of the Gary and Kent types (Figures 3 and 4), bifaces (including large chipped bifacial knives), gouges of petrified wood, and a variety of expedient and formal flake tools. Ground stone tools were also abundant, particularly pitted stones, pitted stone-manos, manos, and grinding slabs (Table 2). Local lithic raw materials dominated the tool inventory. There is no available archaeological evidence for the use of arrow points before the mid- $7^{\text {th }}$ to late $8^{\text {th }}$ centuries A.D., but their apparent absence in such deposits may simply mean that our measurements of time in the Woodland period with artifacts remains far from satisfactory. Nevertheless, a "pure" assemblage of purportedly early arrow points (such as Friley and Steiner arrow points, cf. Corbin 1998:108 and Figure 2; Shafer and Walters 2010) from dated Woodland period contexts was not documented in the Lake Naconiche archaeological assemblages, although such arrow point styles were relatively abundant at the Boyette site (Perttula 2008:Figure 8-21). These arrow points also tended to have serrated and barbed blades, most likely to insure better penetration in the prey they hunted.

By themselves, the composition of the assemblages of stone tools from the Woodland period components are activities strongly geared towards hunting in small groups (or individually), considerable time spent butchering and processing meat and hides, and a noticeable focus on the consumption of wild plant foods, most particularly hardwood mast. The assemblages are fairly standardized in character, especially the hafted dart points, which is seemingly a notable feature of mobile hunter-gatherers who faced uncertainty in raw material access and technological needs, along with the use of expedient tools at the expense of formalized bifacially hafted tools (Odell 2004:197).

\section{4 - Volume 23, 2013}




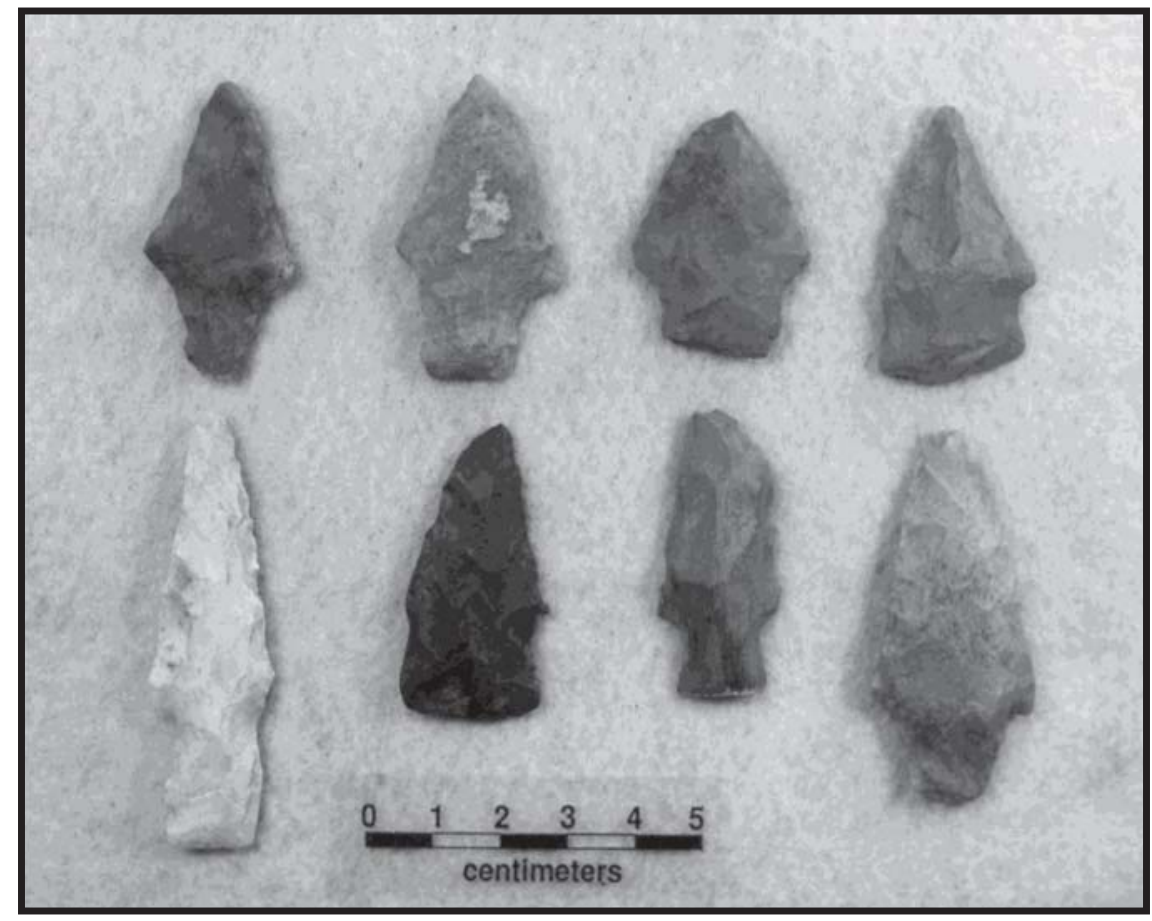

Figure 3. Dart points from Woodland period contexts at the Tallow Grove site.

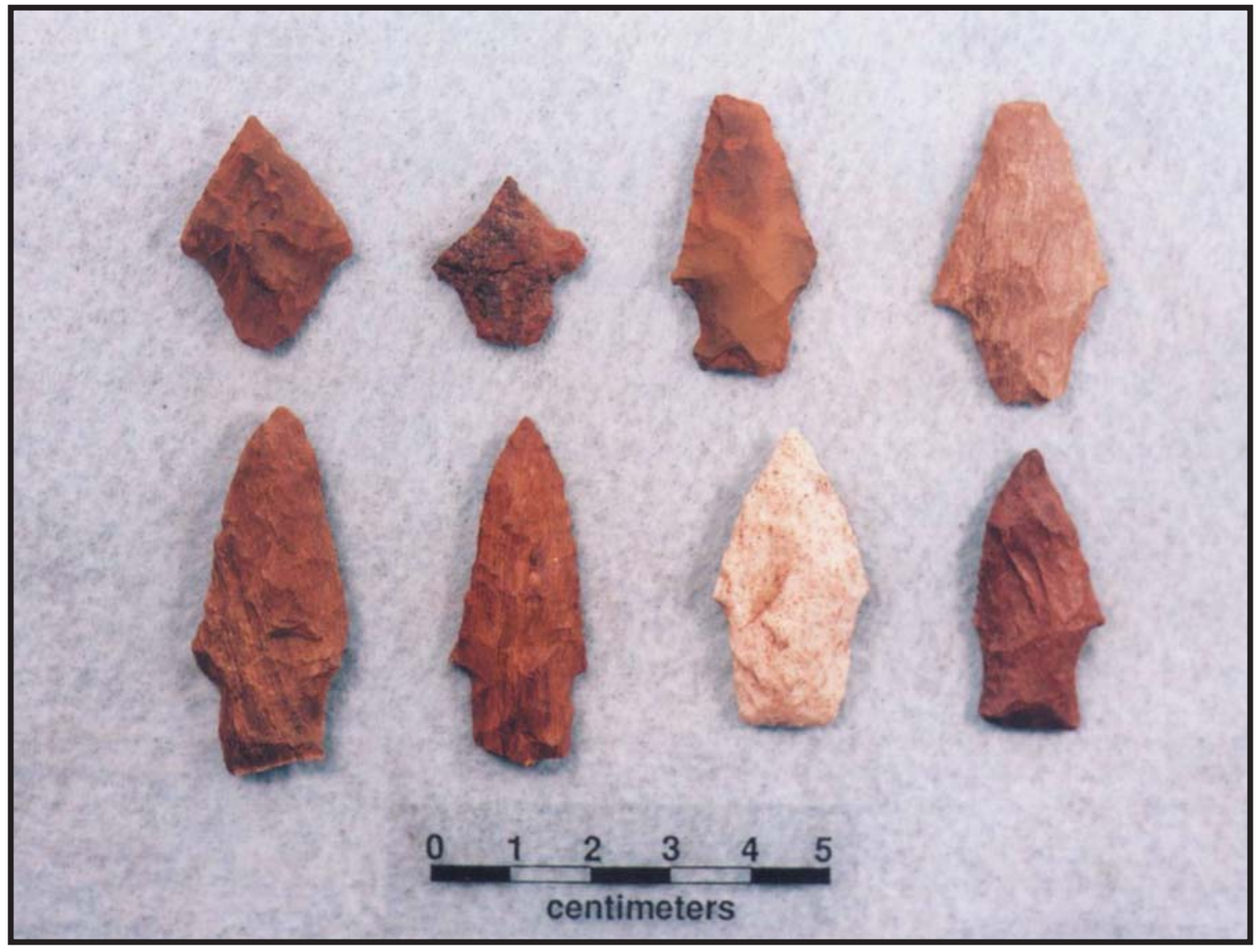

Figure 4. Dart points from Woodland period contexts at the Boyette site. 
The generally low amounts of non-local lithic raw materials in Woodland period occupations at Lake Naconiche suggests that there were technological constraints that would have to have been overcome by tool knappers. These knappers now had to rely on fewer lithic resource options and had less opportunity to pass through lithic source areas during less wide-ranging foraging trips. These people had to design tools that could be efficiently made with the relatively small size of available source materials and the generally poor quality of some of these same raw materials (i.e., much of the blocky petrified wood and the coarse-grained quartzite); they also had to carefully conserve, curate, and extensively resharpen tools in their assemblage that were made from non-local raw materials. Heat treatment of quartzite (and probably some of the local cherts) was one technological solution, as was bipolar flaking of cores and pebbles, along with the ability to produce Gary and Kent points from flakes struck from small cores rather than having to manufacture them by reducing down a core or bifacial preform; these latter points are marked by cortical remnants on the basal portion of the stem.

In other Mossy Grove Culture sites like Deshazo and several components excavated at Lake Sam Rayburn, the principal dart points are contracting stem Gary points of several different varieties, along with Kent dart points and a few Ellis points. They are apparently made almost exclusively of local raw materials. The distinctively barbed Friley arrow points began to be made and used around A.D. 700; Scallorn arrow points were also present in the Woodland period component at Herman Ballew (Rogers et al. 2001:Figure 15). Other tools in Woodland period deposits, again made primarily of local raw materials, included gouges, perforators/ drills, knives, unifaces and other retouched flake tools (i.e., scrapers, gravers), expedient flake tools, and a wide assortment of ground stone tools-such as pitted stones, manos, metates/milling basins, and battered tools (i.e., hammerstones) — used to crush, pulverize, and grind plant materials.

In general, Woodland period groups in northeastern Texas relied heavily on local quartzites, cherts, and petrified woods for tool stone, and this is certainly the case at the Lake Naconiche sites. Quartzite and cherts were clearly preferred for tools in Woodland period times, and the Woodland period assemblages at the Naconiche Creek and Boyette sites are dominated by local chert lithic debris (30-50\%) —and so are they in Woodland period contexts at Herman Ballew (53-72\%, see Rogers et al. 2001) - petrified wood (20-34\%), and quartzite (17-32\%). Cherts were preferred at the Boyette site in Woodland period contexts; the regular use of petrified wood, however, is characteristic of many Woodland and prehistoric Caddo sites in the Angelina and Attoyac stream basins (cf. Girard 1995; Corbin 1998). A few non-local lithic raw materials were used in tool manufacture ( $3 \%$ of the dart points), and in fact, non-local lithics are slightly more common in Woodland period contexts at the Boyette and Naconiche Creek sites than they are in the later Caddo components at the two sites.

\section{Ceramic Assemblages}

Woodland period ceramics in the Neches-Angelina River basins of East Texas, including the Lake Naconiche sites, are sandy paste wares, primarily undecorated Goose Creek Plain, var. unspecified (Aten and Bollich 2002), a common upper Texas Coast ceramic type. Lip notched sandy paste ceramics is characteristic of Mossy Grove ceramics in East Texas sites, and this distinctive lip decorated type appears to have been most commonly used prior to ca. A.D. 300 in East Texas (Perttula 2008). Lower Mississippi Valley ceramic types occur in low numbers in Woodland period contexts (see Table 2). Other kinds of decorated sandy paste pottery (incised, punctated, and incised-punctated) have been documented in a late $7^{\text {th }}-8^{\text {th }}$ century ceramic assemblage in the Attoyac Bayou basin, especially at the Boyette site (Figure 5). 
Table 2. Material Culture Remains on Woodland Period Sites at Lake Naconiche.

\begin{tabular}{lrrrr}
\hline Material Culture remains* & 41NA231 & 41NA236 & 41NA242 & 41NA285 \\
\hline $\begin{array}{l}\text { Lower Mississippi Valley sherds } \\
\text { Sandy paste sherds (Goose Creek } \\
\quad \text { Plain, var. unspecified) }\end{array}$ & 14 & 271 & - & 9 \\
Decorated Sandy paste sherds & 4 & 14 & 4 & 39 \\
Dart points & 25 & 55 & 5 & 123 \\
Large biface & 2 & - & - & - \\
Biface fragments & - & 13 & - & 34 \\
Chopper/Shredder & 1 & 1 & - & - \\
Gouge & - & 4 & - & 4 \\
Scraper & 1 & 3 & - & 1 \\
Perforator & - & - & - & 18 \\
Flake tools & - & 3 & 4 & 25 \\
Ground stone tools & 14 & 41 & 17 & 1350 \\
\hline Totals & 61 & 407 & & \\
\hline
\end{tabular}

* Lithic debris and fire-cracked rock were also present in these components

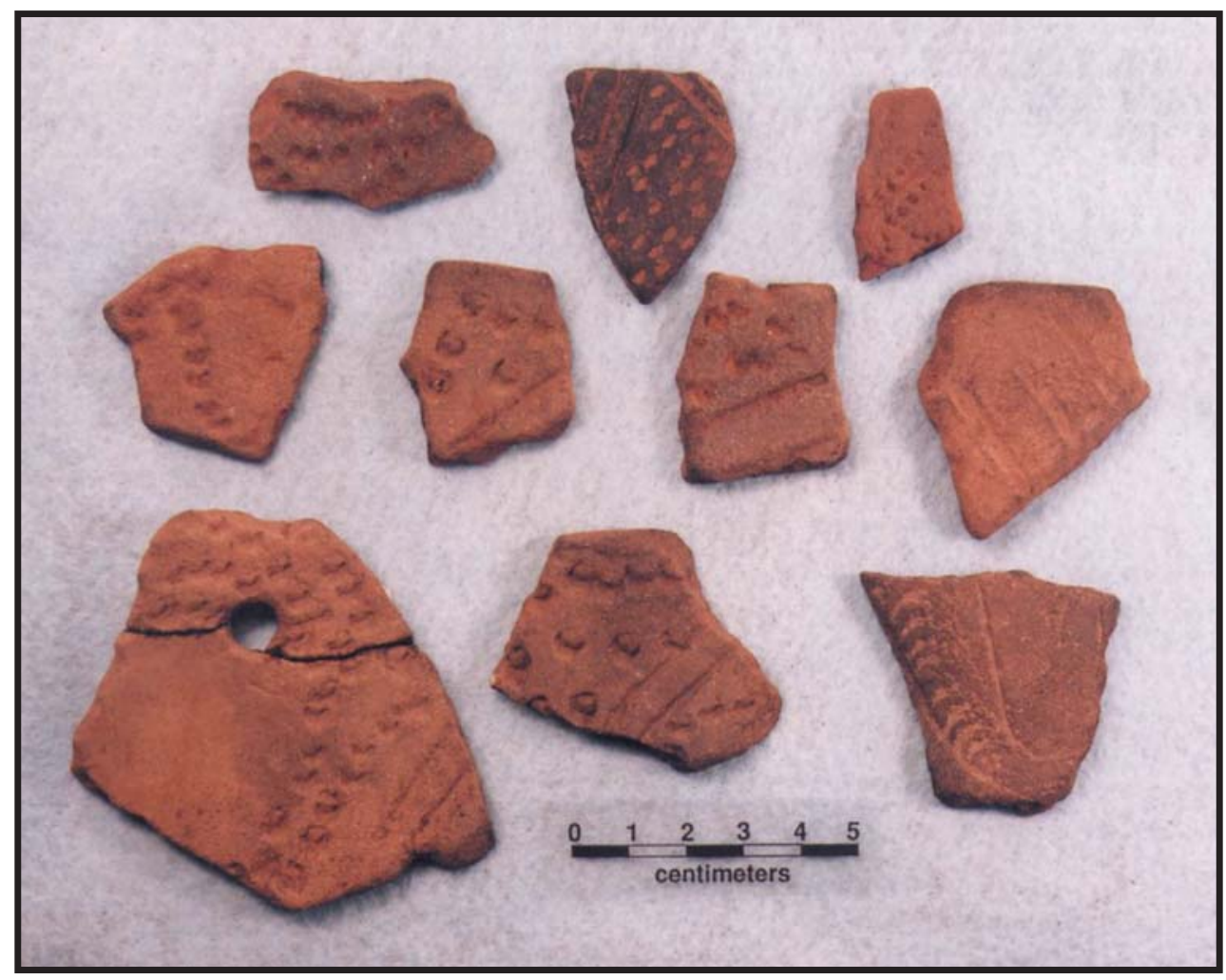

Figure 5. Decorated sandy paste Woodland pottery sherds from the Boyette site. 
In the Red, Sulphur, and parts of the Sabine River basin (cf. Dockall et al. 2008), the ceramics are primarily plain grog and bone-tempered Fourche Maline wares (i.e., Williams Plain) with flat bases and very thick vessel walls (Schambach 2001, 2002). Woodland period ceramics in other parts of the Sabine River basin as well as in the Big Cypress Creek basin are also primarily plain grog-tempered wares (Rogers et al. 2001:124130 and Table 21), but there are also plain sherds with laminated and contorted pastes, similar to Tchefunctelike or Marksville wares that may have been made between ca. 100 B.C and A.D. 200. There are also relatively thick bone-tempered sherds that may be related to Cooper Boneware (see Schambach 1998), another Woodland period ceramic type, as well as sherds with grog temper and a sandy paste, bone temper with a sandy paste, and non-tempered sandy paste sherds. Decorated ceramics with lower Mississippi Valley similarities are notable in these assemblages (including Tchefuncte, Marksville, Troyville, and early Coles Creek types), recently labeled as belonging to the Mill Creek Culture.

The initial appearance of ceramics on Woodland period sites in East Texas after ca. 2500 years B.P. when absolutely dated to establish their temporal context, means that the archaeological study of Woodland period ceramics can contribute new information regarding one of the quintessential Eastern Woodlands research problems: the invention, adoption, and use of ceramics by hunter-gatherer Woodland societies (cf. Rice 1996; Sassaman 2002). That this happened well before the development of agricultural traditions in East Texas is important in examining the practical roles of ceramic vessels in these societies (see Jordan and Zvelebil 2009:54-68). When were ceramics adopted among East Texas Woodland period peoples-was the adoption contemporaneous across the region, and was it a technological tradition (i.e., a new form of container technology that has other technological and social practices, see Jordan and Zvelebil 2009:Figure 1.4) that was shared by different Woodland groups? It has been noted that the prehistoric adoption and initial development of ceramic vessels in general was one best suited, for a variety of reasons, to hunter-gatherer societies that lived in lake and river-edge settings and exploited estuarine and riverine resources (Rice 1999:21; Jordan and Zvelebil 2009:58-59). Perhaps such a technological relationship is apparent in the economic and settlement choices of the earliest ceramic-using Woodland period groups in East Texas.

With respect to the study of Woodland period ceramics, there was a long history (over 1300 years) of use of ceramic vessels among peoples living in the different river basins in the region, but it is not clear if there were changes through time in ceramic manufacture and vessel shapes that represented the evolution of ceramic use for different functional, technological, and social purposes by these groups. It is probably the case that the Woodland period groups in East Texas may have adopted and made use of different ceramic technologies from disparate groups that they interacted with socially.

There appear to be significant variations in the manufacture and use of ceramics (as detected in the simple measure of sherd density) by Woodland period groups. These variations may represent regional differences in food processing and dietary habits between Fourche Maline, Mill Creek, and Mossy Grove Woodland groups that can be detected in the study of ceramic assemblages. It is likely that there were changes in the frequency of boiling food in vessels, along with changes from indirect heating to direct heating using cooking vessels (cf. Sassaman 2002; Nelson 2010), and there may also have been changes from stone to wood preparation tools. All of these technological changes point to an increased consumption of carbohydrate-rich plant foods by some Woodland groups (see Schambach 1998, 2002), and the carbohydrate-rich foods may have included some amount of maize and starchy seeds. The Mossy Grove and Mill Creek Culture groups were primarily hunter-gatherers, with a heavy emphasis on forest mast products and animal resources, with little evidence from either plant or animal remains or the pottery found on sites occupied by these people (cf. Hood 2007) for the consumption or processing of starchy foods or seeds. These plant and animal resources were 
frequently processed in large pits and earth ovens using ground stone tools and hot rock cooking (cf. Rogers et al. 2001). Fourche Maline culture sites do not have such pit features or evidence of much use and discard of fire-cracked rock (FCR) (Frank F. Schambach, 2003 personal communication). FCR and FCR features are found in the Woodland period components at the Naconiche Creek and Boyette sites at Lake Naconiche.

Cooking in ceramic pots versus employing direct heating in open fires or indirect heating using hot rocks may have broadened the range of foods (including both plant foods and game animals) that could be readily or more efficiently cooked by Woodland period groups in East Texas. The familiarity of these Woodland period peoples with a ceramic cooking technology would have created conditions where such foods could be more efficiently cooked if and when such foods (i.e., cultigens) became known to them or their Caddo descendants. Are there changes through time in ceramic manufacture and vessel shape, as well as any evidence for the evolution of ceramic use for different purposes by Woodland period groups?

The occurrence of ceramics-albeit not necessarily in large quantities at any Woodland period culture sites in East Texas-point to the development of some occupational redundancy (i.e., a tethering to certain locations and a repeated and consistent use of those locations) in site use in Woodland period times. In a study of the use of ceramics among residentially mobile hunter-gatherers, Eerkens (2003:736) has suggested that "the degree of occupational redundancy in areas with resources suited to mass collecting and boiling [are]... correlated with pottery use." This occupational redundancy may actually promote long-term trends in decreasing mobility and increasing sedentism, and in such settings the use of pottery may be also "associated with incipient agricultural strategies" (Eerkens 2003:736). Pottery development and use in East Texas Woodland period sites may be related to the mass processing of hickory nuts for their oil, as this was a common subsistence pursuit.

There are sandy paste Goose Creek Plain sherds in the Woodland period component at the Naconiche Creek and Boyette sites, but they are not abundant (see Table 2). Their presence reflects change from Late Archaic times in food processing (i.e., to the direct boiling of foods in vessels and a change from stone to wooden food preparation tools) and dietary habits (i.e., an increased consumption of carbohydrate-rich foods, possibly including maize or small seeds late in the period).

The manufacture and use of sandy paste Goose Creek Plain ceramic vessels in the Lake Naconiche Woodland period sites seems to have remained relatively and remarkably unchanged through more than 1000 years, until the latter part of the $7^{\text {th }}$ century A.D. The same vessel forms (simple bowls and jars) were made throughout that span of time, and there is no evidence in the East Texas archaeological record to suggest that these vessels began to be made, or changed in any respect (except perhaps in their decoration), due to the adoption of new food stuffs or new forms of cooking technology. Hood (2007:5) reports that organic residue signatures from selected Mossy Grove sandy paste sherds of different ages indicate that pottery vessels were used for processing plant foods, especially on sites located on the coastal margin of the upper Texas Coast, but in upland and interior Mossy Grove culture sites, pottery vessels were used for processing plants and largebodied mammals. Such use of pottery vessels was likely also characteristic of the Woodland groups that lived along Naconiche Creek.

The available archaeological evidence suggests that Mossy Grove groups-like those that periodically occupied the Lake Naconiche sites-were more residentially mobile than were Fourche Maline groups living along the Red, lower Sulphur, and Ouachita rivers, with small (at best) middens and settlements, none being occupied for particularly long intervals. To date, no structures have been identified at any Mossy Grove Culture site, and only two burial mounds have been found or recorded in the region (Jelks 1965; McClurkan et al. 1980). 
The occurrence of ceramics-albeit not necessarily in large quantities at any Mossy Grove culture sites-does point to the development of some occupational redundancy (i.e., a tethering to certain locations and a repeated and consistent use of those locations) in site use in Woodland period times.

Ceramics are not at all abundant in Mossy Grove Culture sites when compared to Fourche Maline sites - although they began to be used about the same time (ca. 500 B.C.) —as the latter Woodland sites are likely to have thousands of sherds from many vessels (see Schambach 1998, 2002). In extensive archaeological excavations at the Deshazo site, for example, less than 800 sandy paste sherds were recovered, fewer than 5 sherds per $\mathrm{m}^{3}$ of screened archaeological deposits (Story 1995:Table 1). Similar, if not lower, sherd densities characterize the Lake Naconiche Woodland period archaeological deposits at the Naconiche Creek and Boyette sites.

The ceramics that are present in Mossy Grove Culture sites are sandy paste wares, primarily undecorated Goose Creek Plain, var. unspecified (Aten and Bollich 2002; Hood 2007), at least in components that date before ca. the $7^{\text {th }}$ century A.D. Lip notched sandy paste pottery is characteristic of Mossy Grove ceramics, and at Lake Naconiche, this distinctive lip decorated type appears to have been most commonly used prior to ca. A.D. 300. Pre-A.D. 400 sandy paste ceramics at Lake Naconiche are almost exclusively plain wares, with the exception of the previously mentioned occasional lip notched rim sherd or incised (Marksville Incised) and rocker stamped Lower Mississippi valley trade wares (Figure 6). The post-A.D. 400 sherds at Herman Bellew are primarily grog-tempered, including at least one thick grog-tempered vessel section; smoothed sandy paste sherds; grogtempered sandy paste sherds; a possible French Fork Incised, var. Larkin sherd; and another incised sherd that resembles Coles Creek Incised, var. Hunt or Marksville Incised, var. Yokena. At Lake Naconiche, the post-A.D. 400 ceramics remain sandy paste Goose Creek Plain wares, but the frequency of decorated sandy paste wares seems to have increased by the time of the $7^{\text {th }}$ century A.D. occupation at the Boyette site. There, the decorated sandy paste sherds include simple straight and geometric designs made with incised, incised-punctated, and punctated decorative methods.

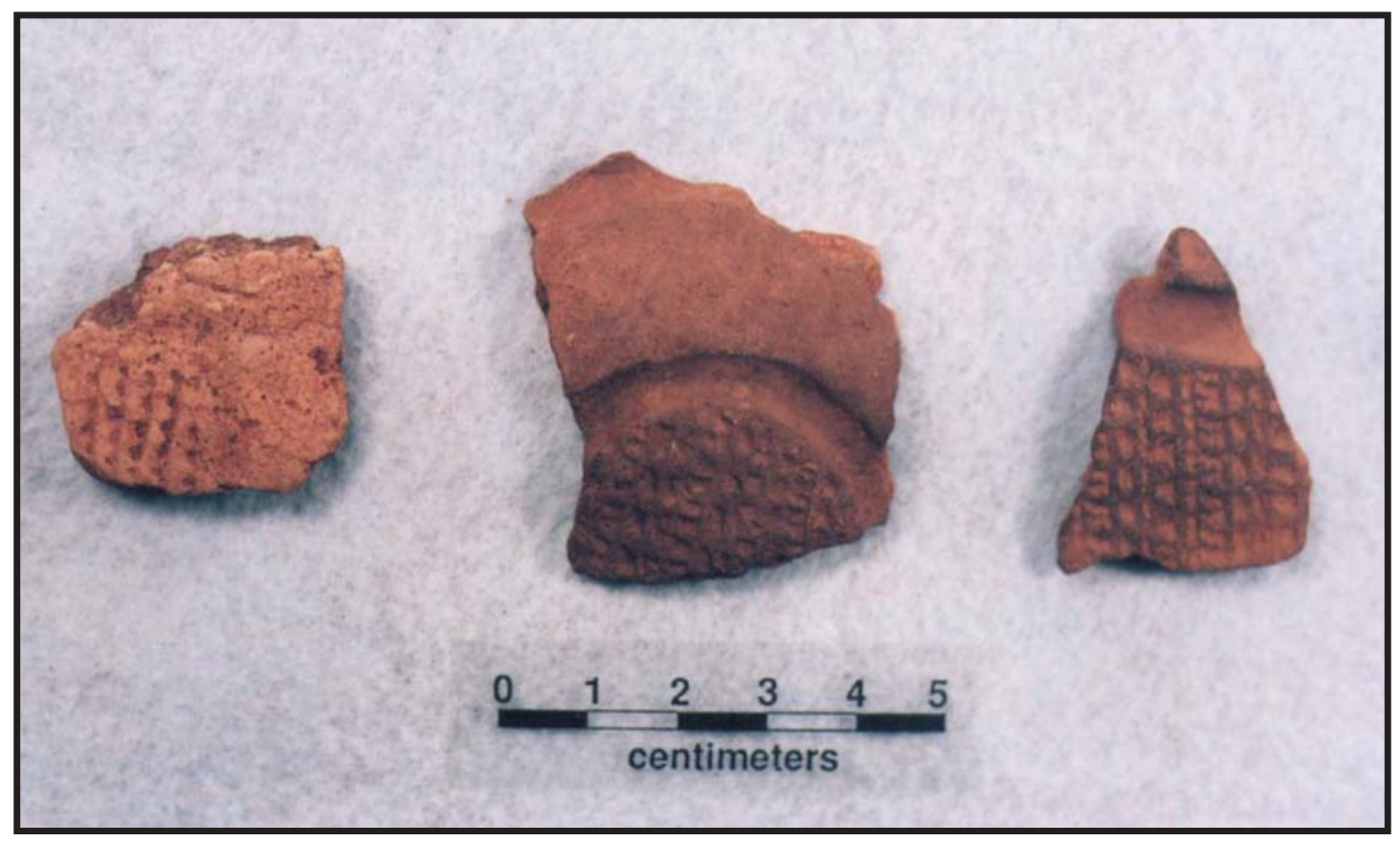

Figure 6. Lower Mississippi Valley stamped ceramic sherds from the Boyette site. 
It is probably the case that the Woodland period groups in East Texas may have adopted and made use of different ceramic technologies from disparate groups that they interacted with socially, namely the grog and bone tempered Fourche Maline wares with plain flat-based bowls and the non-tempered sandy paste Mossy Grove wares with round-based vessels. The Mill Creek Culture component at the Broadway site (41SM273) in the upper Angelina River basin, for example, had only a few non-tempered sandy paste sherds $(n=7)$ and tempered sandy-paste sherds $(n=8)$ (Perttula and Nelson 2004). Perhaps more likely, given the adoption of ceramics by 500 B.C. by Woodland period groups, was that there was a long history of use of ceramic vessels among peoples living in the different river basins, and there were changes through time in ceramic manufacture and vessel shapes that represented the evolution of ceramic use for different functional, technological, and social purposes by Mossy Grove and Mill Creek Woodland period groups.

\section{Exchange and Interaction with Neighboring Groups}

The presence of non-local lithic raw materials (exotic cherts) in the Woodland period components suggest that patterns of long-distance exchange and interaction can be detected by examining the proportions of local vs. non-local lithic raw materials. These patterns may have broader economic implications relating to the evolution of sedentary life in East Texas.

The occurrence of non-local lithic raw materials-in the form of completed tools as well as pieces of primarily non-cortical lithic debris-does indicate that glimpses of the existence of long-distance trade and exchange relationships can be documented in the Lake Naconiche archaeological record. The evidence from chipped stone tools and lithic debris indicate that although not substantial (ca. 3-10\%, respectively, among both lithic categories), obtaining non-local lithic raw materials and finished tools was an important aspect of life for Woodland period groups. Procuring such materials led to broad-ranging contacts between related (both culturally and perhaps genetically) Woodland groups living well to the north of Naconiche Creek and to unrelated groups living in the prairies of Central Texas.

The archaeological record from the Lake Naconiche sites documents a gradual, yet substantial, diminishment in the use of non-local lithic raw materials from Archaic times (ca. 8000-500 B.C.) to the Woodland period. This clearly indicates that if there was an increasingly recurrent and repetitive use of smaller territories by Woodland groups who did not necessarily always move with the seasons, that trend was occupied by an increasing reliance on local sources of lithic raw material, and a more limited access to stone from long-distance sources.

This sparse occurrence of non-local lithic raw materials is perhaps the best available evidence from the sites at Lake Naconiche that its occupants were interacting with their Woodland period neighbors, exchanging tools, raw materials, and ideas concerning all manner of things. Associated with the construction and use of burial mounds at this time at the Jonas Short and Coral Snake mounds (Jelks 1965; Story 1990) were costly non-local raw materials and artifacts, including cherts, copper, and Lower Mississippi valley ceramic vessels that were included as grave goods or caches in the burial mounds, and ended up as trade wares in habitation sites (see Figure 6). Perhaps the non-local raw materials and tools in local Woodland period contexts at Lake Naconiche were procured and disbursed from these sacred mound centers. 
The principal non-local lithic raw material in Woodland period contexts is a dark gray chert, most likely available in the Edwards Formation cherts from parts of Central Texas, and probably also available in regional gravel sources (i.e., the Trinity and Neches river valleys to the west of Lake Naconiche, see Girard 1995). Other non-local lithic raw materials in Woodland period contexts include white novaculite, black chert (Big Fork chert), a dark brown chert, quartz, and a greenish-brown chert. On balance, when comparing the use of nonlocal lithic raw materials as seen in projectile points and lithic debris, there is no significant difference between the Woodland and Caddo procurement and use of non-local lithic raw materials at the Lake Naconiche sites (3-10\% in Woodland components and 5-7\% in later Caddo components), and the higher frequency of non-local lithics in the tools compared to the lithic debris also suggests that these tools were probably being obtained as completed tools, and perhaps only being resharpened/maintained at the Lake Naconiche sites.

\section{Conclusions}

Sometime after around ca. A.D. 800, the sites at Lake Naconiche were no longer occupied by Woodland period groups making primarily plain sandy paste pottery or living as mobile hunting-gathering foragers. At this time, from ca. A.D. 750-800 to around A.D. 900 (see Perttula and Nelson 2004:Figures 4 and 5), colder and drier conditions began to dominate the local weather, but climatic conditions were not sufficiently extreme to lead to an abandonment of the area. After ca. A.D. 800, were the aboriginal groups living in the Attoyac Bayou basin Caddo peoples or acculturated Mossy Grove folks? Some findings from the Lake Naconiche archaeological investigations may be relevant to this issue of ethnic affiliations and local cultural changes, but that is the subject of another article. Suffice it to say that changes that occurred from Woodland period times to the earliest Caddo period in East Texas represent the start of a momentous series of macro-evolutionary events (e.g., Chatters 2009) at local and regional scales.

The Woodland period archaeological record at Lake Naconiche in East Texas provides few hints of what was to come after ca. A.D. 800. The Mossy Grove Culture peoples that occupied the area from as early as 2500 years ago relied on wild plant and animal foods for sustenance, did not live in large communities nor settle in any one place for long as they ranged year by year through the East Texas Pineywoods. There is archaeological evidence that they had contact with neighboring groups in East Texas, coastal Texas, and Central Texas, and there was interaction between these Mossy Grove Culture people and societies living in the Lower Mississippi Valley. Their technology was based on the manufacture of sandy paste Goose Creek Plain cooking jars. The cooking of food stuffs in ceramic pots was a change from an earlier cooking technology that employed direct heating in open fires or indirect heating using hot rocks, and this may have eventually broadened the range of foods (including both plant foods and game animals) that could be readily or more efficiently cooked or processed (such as hardwood nut meats and oil). The stone tools from the Woodland period components at Lake Naconiche suggest that they were used in activities strongly geared towards hunting in small groups (or individually), considerable time spent butchering and processing meat and hides, and a noticeable focus on the processing and consumption of wild plant foods, most particularly hardwood mast.

Radiocarbon dates from the Lake Naconiche sites, a possible storage pit feature, and the regular presence of ceramics hints at the beginnings of a more settled way of life during the latter part (after ca. A.D. 500/600) of the Woodland period. The best archaeological evidence of this process is apparent in the manufacture and use of ceramic vessels for cooking, storage, and food-serving at the Naconiche Creek (41NA236) and Boyette (41NA285) sites, as this implies that more extended stays may have occasionally taken place at them. 


\section{Acknowledgements}

Sandy Hannum drafted the maps in this article, and Bo Nelson took the photographs of the ceramic and lithic artifacts. I also want to acknowledge Bo for his excellent work as Project Archeologist during all phases of archaeological work at Lake Naconiche. Thanks also to Robert Z. Selden, Jr. for discussions concerning the radiocarbon database for Woodland period sites in East Texas, and for providing useful comments on an earlier version of this paper.

\section{References Cited}

Aten, L, E. and C. N. Bollich

1969 A Preliminary Report on the Development of a Ceramic Chronology for the Sabine Lake Area of Texas and Louisiana. Bulletin of the Texas Archeological Society 40: 241-258.

2002 Late Holocene Settlement in the Taylor Bayou Drainage Basin: Test Excavations at the Gaulding Site (41JF27), Jefferson County, Texas. Studies in Archeology 40, Texas Archeological Research Laboratory, The University of Texas at Austin, and Special Publication No. 4, Texas Archeological Society, San Antonio.

Bradley, R. S., K. R. Briffa, J. Cole, M. K. Hughes, and T. J. Osborn

2003 The Climate of the Last Millennium. In Paleoclimate, Global Change and the Future, edited by K. D. Alverson, R. S. Bradley, and T. F. Pedersen, pp. 105-141. Springer-Verlag, Berlin.

Chatters, J. C.

2009 A Macroevolutionary Perspective on the Archaeological Record of North America. In Macroevolution in Human Prehistory: Evolutionary Theory and Processual Archaeology, edited by A. M. Prentiss, I. Kuijt, and J. C. Chatters, pp. 213-234. Springer, New York.

Corbin, J. E.

1989 The Woodland/Caddo Transition in the Southern Caddo Area. In In the Light of Past Experience: Papers in Honor of Jack T. Hughes, compiled and edited by B. C. Roper, pp. 117-124. Publication No. 5. Panhandle Archeological Society, Clarendon.

1998 Reflections on the Early Ceramic Period and the Terminal Archaic in South Central East Texas. Journal of Northeast Texas Archaeology 11:108-116.

Dering, J. P.

2001 Plant Remains from 41RK222, Rusk County, Texas. In Excavations at the Herman Ballew Site (41RK222), Rusk County, Texas, by R. Rogers, M. A. Nash, and T. K. Perttula, pp. A-1 to A-12. Document No. 000021. PBS\&J, Austin.

2002 Plant Remains from Prehistoric Archeological Sites in Nacogdoches County: The Lake Naconiche Project. In Archeological Investigations at the Proposed Lake Naconiche, Nacogdoches County, Texas, edited by T. K. Perttula, pp. 315-321. 2 Vols. Report of Investigations No. 42. Archeological and Environmental Consultants, Austin.

Dockall, J. E., S. I. Katauskas, and R. Fields

2008 National Register Testing of Four Sites in the Sabine Mine's Area M, Harrison County, Texas. Reports of Investigations No. 157. Prewitt \& Associates, Inc., Austin. 


\section{References Cited (cont.)}

Early, A. M.

2004 Prehistory of the Western Interior after 500 B.C. In Handbook of North American Indians, Southeast, Volume 14, edited by R. B. Fogelson, pp. 560-573. Smithsonian Institution, Washington.

Eerkens, J. W.

2003 Residential Mobility and Pottery Use in the Western Great Basin. Current Anthropology 44(5):728738.

Fields, R. C.

1995 Analysis of Native-Made Ceramics. In The Deshazo Site, Nacogdoches County, Texas, Volume 2: Artifacts of Native Manufacture, edited by D. A. Story, pp. 173-232. Studies in Archeology 21. Texas Archeological Research Laboratory, The University of Texas at Austin.

Fields, R. C., M. E. Blake, and K. W. Kibler

1997 Synthesis of the Prehistoric and Historic Archeology of Cooper Lake, Delta and Hopkins Counties, Texas. Reports of Investigations No. 104. Prewitt and Associates, Inc., Austin.

Girard, J. S.

1995 The Chipped Stone Collection: Technological, Functional, and Typological Analyses. In The Deshazo Site, Nacogdoches County, Texas, Volume 2: Artifacts of Native Manufacture, edited by D. A. Story, pp. 33-156. Studies in Archeology 21. Texas Archeological Research Laboratory, The University of Texas at Austin.

2009a Issues Regarding the Early Development of Caddo Culture Discussion Topics for the East Texas Caddo Research Group, December 2008. Journal of Northeast Texas Archaeology 31:47-48.

2009b Comments on Caddo Origins in Northwest Louisiana. Journal of Northeast Texas Archaeology 31:51-60.

Gremillion, K. J.

2002 The Development and Dispersal of Agricultural Systems in the Woodland Period Southeast. In The Woodland Southeast, edited by D. G. Anderson and R. C. Mainfort, Jr., pp. 483-501. University of Alabama Press, Tuscaloosa.

Hood, L.

2007 Modeling Hunter-gatherer Ceramic Production and Use: A Test Case from the Upper Texas Coastal Plain. Ph.D. dissertation, Department of Anthropology, University of Washington, Seattle.

Jelks, E. B.

1965 The Archeology of McGee Bend Reservoir. Ph.D. dissertation, Department of Anthropology, The University of Texas at Austin.

Jordan, P. and M. Zvelebil

2009 Ex Oriente Lux: The Prehistory of Hunter-Gatherer Ceramic Dispersals. In Ceramics Before Farming: The Dispersal of Pottery Among Prehistoric Eurasian Hunter-Gatherers, edited by P. Jordan and M. Zvelebil, pp. 33-89. Left Coast Press, Walnut Creek, California.

\section{4 - Volume 23, 2013}




\section{References Cited (cont.)}

McClurkan, B. B., E. B. Jelks, and H. P. Jensen

1980 Jonas Short and Coral Snake Mounds: A Comparison. Louisiana Archaeology 6:173-206.

Nelson, K.

2010 Environment, cooking strategies and containers. Journal of Anthropological Archaeology 29(2):238247.

Odell, G. H.

2004 Lithic Analysis. Kluwer Academic/Plenum Publishers, New York.

Perttula, T. K.

1998 A Compendium of Radiocarbon and Oxidizable Carbon Ratio Dates from Archaeological Sites in East Texas, with a Discussion of the Age and Dating of Select Components and Phases. Radiocarbon 39(3):305-341.

2008 Caddo Agriculture on the Western Frontier of the Eastern Woodlands. Plains Anthropologist 53(205):79-105.

Perttula, T. K. (editor)

2002 Archeological Investigations at the Proposed Lake Naconiche, Nacogdoches County, Texas. 2 Vols. Report of Investigations No. 42. Archeological and Environmental Consultants, Austin.

2008 Lake Naconiche Archeology, Nacogdoches County, Texas: Results of the Data Recovery Excavations at Five Prehistoric Archeological Sites. 2 Vols. Report of Investigations No. 60. Archeological \& Environmental Consultants, LLC, Austin.

Perttula, T. K. and B. Nelson

2004 Woodland and Caddo Archeology at the Broadway or Kanduts'ah Kuhnihdahahdisa' Site (41SM273) on the City of Tyler-Lake Palestine WTP Project, Smith County, Texas. Report of Investigations No. 50. Archeological \& Environmental Consultants, LLC, Austin.

Perttula, T. K., and R. Z. Selden Jr.

2011 East Texas Radiocarbon Database. Electronic resource. http://counciloftexasarcheologists. org/?page_id=27, accessed January 2012.

Rice, P. M.

1996 Recent Ceramic Analysis: 1. Function, Style, and Origins. Journal of Archaeological Research 4(2):133-163.

1999 On the Origins of Pottery. Journal of Archaeological Method and Theory 6(1):1-54.

Rogers, R., M. A. Nash, and T. K. Perttula

2001 Excavations at the Herman Ballew Site (41RK222), Rusk County, Texas. Document No. 000021. PBS\&J, Austin.

Sassaman, K. E.

2002 Woodland Ceramic Beginnings. In The Woodland Southeast, edited by D. G. Anderson and R. C. Mainfort, Jr., pp. 398-420. University of Alabama Press, Tuscaloosa. 


\section{References Cited (cont.)}

Schambach, F. F.

1982 An Outline of Fourche Maline Culture in Southwest Arkansas. In Arkansas Archeology in Review, edited by N. L. Trubowitz and M. D. Jeter, pp. 132-197. Research Series No. 15. Arkansas Archeological Survey, Fayetteville.

1998 Pre-Caddoan Cultures in the Trans-Mississippi South: A Beginning Sequence. Research Series No. 53. Arkansas Archeological Survey, Fayetteville.

2001 Fourche Maline and its Neighbors: Observations on an Important Woodland Period Culture of the Trans-Mississippi South. The Arkansas Archeologist 40:21-50.

2002 Fourche Maline: A Woodland Period Culture of the Trans-Mississippi South. In The Woodland Southeast, edited by D. G. Anderson and R. C. Mainfort, Jr., pp. 91-112. University of Alabama Press, Tuscaloosa.

Selden, R. Z., Jr.

2012 Modeling Regional Radiocarbon Trends: A Case Study from the East Texas Woodland Period. Radiocarbon 54(2):239-265.

Shafer, H. J. and M. Walters

2010 The Browning Site (41SM195A) Lithics: Considering Patterns of Identity and Interaction through Lithic Analysis. Bulletin of the Texas Archeological Society 81:127-151.

Story, D. A.

1990 Cultural History of the Native Americans. In The Archeology and Bioarcheology of the Gulf Coastal Plain, by D. A. Story, J. A. Guy, B. A. Burnett, M. D. Freeman, J. C. Rose, D. G. Steele, B. W. Olive, and K. J. Reinhard, pp. 163-366. 2 Vols. Research Series No. 38. Arkansas Archeological Survey Research Series, Fayetteville.

2000 Introduction. In The George C. Davis Site, Cherokee County, Texas, by H.P. Newell and A.D. Krieger, pp. 1-31. 2nd Edition. Society for American Archaeology, Washington, D.C.

Story, D. A. (editor)

1982 The Deshazo Site, Nacogdoches County, Texas: Volume 1. Texas Antiquities Permit Series No. 7. Texas Antiquities Committee, Austin.

1995 The Deshazo Site, Nacogdoches County, Texas, Volume 2: Artifacts of Native Manufacture. Studies in Archeology 21. Texas Archeological Research Laboratory, The University of Texas at Austin.

Tunnell, C. D.

1961 Evidence of a Late Archaic Horizon at Three Sites in the McGee Bend Reservoir, San Augustine County, Texas. Bulletin of the Texas Archeological Society 30:123-158.

Webb, C. H., F. E. Murphey, W. G. Ellis, and H. R. Green

1969 The Resch Site, 41HS16, Harrison County, Texas. Bulletin of the Texas Archeological Society 40:3106.

Wyckoff, D. G.

1980 Caddoan Adaptive Strategies in the Arkansas Basin of Eastern Oklahoma. Ph.D. dissertation, Department of Anthropology, Washington State University, Pullman. 